\title{
Capital Inflows and National Debt
}

\author{
EATZAZ AHMAD
}

\begin{abstract}
Using a three-gap model, this paper simulates the future time paths of resource deficits in Pakistan. The paper then show that the policy of increasing the rate of return on foreign capital can reduce foreign debt when foreign capital is sufficiently responsive to changes in its rate of return. This, however, happens at the expense of increasing domestic debt. The policy of selling public assets abroad appears fruitless. The main benefit of this policy is a reduction in domestic debt which can better be achieved by selling public assets domestically.
\end{abstract}

\section{INTRODUCTION}

Pakistan is currently facing severe resource constraints due to growing the volume of external and internal debt. Although a sustainable solution to the problem lies in raising the national saving rate through the much needed reforms towards increasing productivity in the economy, the policy-makers instead have been content with various measures for a short term relief. The most commonly adopted approach has been to roll-over the existing debt. A few half-hearted attempts have recently been made to replace foreign debt with private foreign capital by creating a competitive environment that promises better returns on investment, and through the sale of public-sector enterprises to potential foreign investors.

This study explores the effects of two different policies of attracting foreign investment on foreign borrowing and debt. One of these policies is to increase the rate of return on foreign capital and the other is to sell public-sector enterprises to foreign investors. Most of the earlier studies on foreign investment have concentrated on its role in economic growth. The general conclusion has been that foreign investment does not bring any sustainable benefits unless it favourably affects fundamentals of the economy such as the saving rate or the rate of technological progress [see, for example, Ahmad and Paul (1994) and Crouch (1973)].

Our study is not much different from the studies on the role of foreign investment in growth models except that the increased foreign investment in the present context are assumed to be utilised in reducing foreign borrowing rather than increasing the growth rate of GDP. As such it can be expected that a permanent solution to the external debt problem does not necessarily lie in attracting foreign investment. However, it is still useful to settle the issue in the framework of 
conventional gap models (rather than the growth model) that are frequently used to study the dynamics of foreign debt. The analysis is carried out in the framework of a three-gap simulation model that provides sufficient dynamic linkages across the current and capital account balances in the private, public and foreign transactions.

The paper is planned as follows. Section 2 presents the structure of the threegap model. In Section 3 the effects of the two policies on the future time paths of foreign and domestic borrowing and debt are studied under alternative assumptions. Finally, Section 4 concludes the paper.

\section{THE MODEL}

Following the standard procedure [e.g., Easterly and Schmidt-Hebbel (1993) and Tanzi et al. (1988)], we use national income accounts to express the primary foreign deficit in term of the primary fiscal and private sector's deficits:

$$
\begin{aligned}
& I M_{i}-X_{i}-Q_{i}=\left(G_{i}+I_{g i}-T_{i}\right)+\left(C_{i}+I_{p i}+T_{i}-Y_{i}-Q_{i}\right)
\end{aligned}
$$

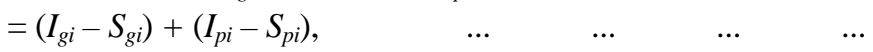

where $I M_{i}, X_{i}$ and $Q_{i}$ are imports, exports and net unrequited transfers from abroad in period $i ; G_{i}$ and $C_{i}$ are government and private consumption expenditure; $I_{g i}$ and $I_{p i}$ are government and private investment expenditures; $T_{i}$ is the tax and non-tax government revenue plus the surplus of government enterprises, $Y_{i}$ is the GDP, $S_{g i}=T_{i}-G_{i}$ and $S_{p i}$ $=Y_{d i}-C_{i}$ are the government and private savings and $Y_{d i}=Y_{i}+Q_{i}-T_{i}$ is the private sector's disposable income. All the variables are measured in local currency at constant prices.

Generalising Naqvi's (1970) two-gap results, we can show that the time paths of primary resource deficits are given by the dynamic equations: ${ }^{1}$

$$
\begin{aligned}
& I_{g i}-S_{g i}=\left(I_{g i-1}-S_{g i-1}\right)+\left[\left(\lambda_{i} k_{i} n_{i+1}-\lambda_{i-1} k_{i-1} n_{i}\right) / n_{i}\right. \\
& \left.+\lambda_{i} k_{i} n_{i+1}-\left(t_{i}-g_{i}\right)\right] n_{i} Y_{i-1}, \quad \ldots \quad \ldots \quad \quad \ldots \\
& I_{p i}-S_{p i}=\left(I_{p i-1}-S_{p i-1}\right)+\left[\left\{\left(1-\lambda_{i}\right) k_{i} n_{i+1}-\left(1-\lambda_{i-1}\right) k_{i-1} n_{i}\right\} / n_{i}\right. \\
& \left.+\left(1-\lambda_{i}\right) k_{i} n_{i+1}-s_{i}\left(1+q_{i}-t_{i}\right)\right] n_{i} Y_{i-1}, \quad \ldots \quad \ldots \\
& I M_{i}-X_{i}-R_{i}=\left(I M_{i-1}-X_{i-1}-R_{i-1}\right)+\left[\left(k_{i} n_{i+1}-k_{i-1} n_{i}\right) / n_{i}+k_{i} n_{i+1}\right. \\
& \left.-\left\{\left(t_{i}-g_{i}\right)+s_{i}\left(1+q_{i}-t_{i}\right)\right\}\right] n_{i} Y_{i-1}, \quad \ldots \quad \ldots
\end{aligned}
$$

where $\lambda, k$ and $n$ are respectively the share of public sector in total investment, the incremental capital-output ratio and the growth rate of GDP; $t, g$ and $q$ are the marginal rates of tax, government consumption expenditure and unrequited transfers from 
abroad per rupee of GDP and $s$ is the marginal private saving rate per rupee of disposable income.

Since the primary resource deficits are measured in local currency, the interest payments on foreign debt and rental payments on the private foreign capital must also be denominated in local currency for the purpose of aggregation. Further, since the interest and capital rental payments are made in nominal terms, primary resource deficits should also be escalated over time by price inflation. Further assuming that full Fisher effects of inflation are operative, the nominal values of the exchange rate depreciation factor, the rental factor on private foreign capital, and the interest factor on foreign and domestic debt are adjusted one to one with inflation. Thus the time paths of the current account and budget deficits, $C A D_{i}$ and $B D_{i}$ respectively, are:

$$
\begin{aligned}
& C A D_{i}=\left(1+\pi_{i}\right)\left(I M_{i}-X_{i}-R_{i}\right)+r_{f i}\left(1+e_{i}\right) F D_{i-1}+\left\{\left(1+\rho_{i}\right)\left(1+\pi_{i}\right)-1\right\}\left(1+e_{i}\right) F K_{i-1},(5) \\
& B D_{i}=\left(1+\pi_{i}\right)\left(I_{g i}-S_{g i}\right)+r_{f i}\left(1+e_{i}\right) F D_{i-1}+\left\{\left(1+r_{d i}\right)\left(1+\pi_{i}\right)-1\right\} D D_{i-1},
\end{aligned}
$$

where $r_{f}$ is the interest rate on foreign debt fixed in nominal foreign currency; $\rho$ is the real rate of return on the private foreign capital; $r_{d}$ is the real rate of interest on domestic debt; $e$ is the rate of nominal exchange rate depreciation; $\pi$ is the domestic inflation rate; and $F D_{i-1}, F k_{i-1}$ and $D D_{i-1}$ are foreign debt, the private foreign capital and domestic debt at the end of period $i-1$ measured in local currency.

The net foreign borrowing equals the current account deficit minus net private capital inflow $\triangle F K$ plus the change in foreign reserves $\triangle F R$ [see Cohen (1988)]. The net domestic borrowing equals the budget deficit minus net foreign borrowing plus change in foreign reserves minus monetary borrowing or the change in high powered money $\Delta M$. That is,

$$
\begin{array}{lllll}
F B_{i}=C A D_{i}-\Delta F K_{i}+\Delta F R_{i}, & \ldots & \ldots & \ldots & \ldots \\
D B_{i}=B D_{i}-F B_{i}+\Delta F R_{i}-\Delta M_{i} . & \ldots & \ldots & \ldots & \ldots
\end{array}
$$

Foreign debt in period $i$ equals foreign debt at the end of period $i-1$, escalated by the exchange rate depreciation, plus the net foreign borrowing during period $i$. Likewise domestic debt in period $i$ equals the last period's domestic debt plus the net domestic borrowing during period $i$. That is,

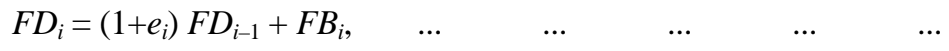

$$
\begin{aligned}
& \begin{array}{lllllll}
D D_{i}=D D_{i-1}+D B_{i}, & \ldots & \ldots & \ldots & \ldots & \ldots
\end{array}
\end{aligned}
$$


The time paths of money supply, foreign reserves and foreign capital can be traced using their growth rates and the initial values:

$\begin{array}{ccccccc}\Delta M_{i}=G_{M i} M_{i-1}, & \ldots & \ldots & \ldots & \ldots & \ldots & \ldots \\ \Delta F R_{i}=G_{F R i} F R_{i-1}, & \ldots & \ldots & \ldots & \ldots & \ldots & \ldots \\ \Delta F K_{i}=G_{F K i} F K_{i-1}, & \ldots & \ldots & \ldots & \ldots & \ldots & \ldots\end{array}$

where $G_{M}, G_{F R}$ and $G_{F K}$ are the growth rates of money supply, foreign reserves and foreign capital respectively. It is assumed that the growth rates $G_{m}$ and $G_{F R}$ are exogenous; determined by monetary authority. Finally, the growth rate of foreign capital $G_{F K}$ is initially also assumed to be exogenously fixed.

We now discuss the implications of two different policies that can affect the growth rate of foreign capital. The first policy to attract capital inflow is to increase the real rental on foreign capital $\rho$. But an increase in $\rho$ also means increased payment of factor income abroad. The net effect of increasing $\rho$ depends on sensitivity of the growth rate of foreign capital $G_{F K}$ to changes in $\rho$. This sensitivity is measured by a linear response function:

$$
\Delta G_{F K i}=\beta \Delta \rho_{i}, \quad \ldots \quad \ldots \quad \ldots \quad \ldots \quad \ldots
$$

We can determine the numerical range of $\beta$ for which the proposed policy can favourably effects resource deficits by conducting iterative experiments with the model. This exercise will be done in the next section.

The second policy is to sell public-sector enterprises to foreign investors. The effectiveness of this policy depends on the degree of crowding out of the foreign capital inflow. Disinvestment through sale of public assets means a decrease in net investment in the public sector. This in turn reduces the public sector's share in investment expenditure $\lambda$ and increases the private sector's share, including the foreign investment, $1-\lambda$. The change in the nominal value of the stock of foreign capital in period $i \delta F K_{i}$ following a permanent reduction in $\lambda$ by $\Delta \lambda$ taking place from period 1 is:

$$
\begin{aligned}
\delta F K_{i} & =\left(1-\gamma_{1}\right)\left[\left(1+\pi_{\mathrm{i}}\right) . .\left(1+\pi_{1}\right) I_{i}+\ldots . .+\left(1+\pi_{1}\right) I_{1}\right] \Delta \lambda \\
& =\left(1-\gamma_{1}\right)\left[\left(1+\pi_{\mathrm{i}}\right) . .\left(1+\pi_{1}\right) k_{i} n_{i+1} Y_{i}+\ldots . .+\left(1+\pi_{1}\right) k_{1} n_{2} Y_{1}\right] \Delta \lambda \\
& =\left(1-\gamma_{1}\right)\left[k_{i} n_{i+1}\left(1+\pi_{i}\right)\left(1+n_{i}\right) . .\left(1+\pi_{1}\right)\left(1+n_{1}\right)+\ldots . .+k_{1} n_{2}\left(1+\pi_{1}\right)\left(1+n_{1}\right)\right] Y_{0} \Delta \lambda
\end{aligned}
$$

where $\gamma$ measures the degree of crowding out. If $\gamma=1$ then the purchase of public assets by foreign investors results in an equal reduction in foreign investment in other sector while $\gamma=0$ means that no such crowding out takes place. A value of $\gamma$ between 0 
and 1 represents partial crowding out. Finally, $\gamma<0$ means crowding-in, that is the sale of public assets opens door for further investment. For example, once the foreign investors establish their business, they may discover it worth while to expand business. If $\gamma, \pi, k, n$ and $G_{F K}$ are constant over time, the above equation simplifies as

$$
\delta F K_{i}=(1-\gamma) k n[(1+\pi)(1+n) /(\pi n+\pi+n)]\left[(1+\pi)^{i}(1+n)^{i}-1\right] Y_{0} \Delta \lambda
$$

The growth rate of foreign capital $G_{F K i}^{\prime}=\left(F K_{i}-F K_{i-1}\right) / F K_{i-1}$ including the effect of a permanent reduction in $\lambda$ taking place in period 1 can be shown to be:

$$
G_{F K i}^{\prime}=\frac{G_{F K}\left(1+G_{F K}\right)^{i-1} F K_{0}+(1-\gamma) k n(1+\pi)^{i}(1+n)^{i} Y_{0} \Delta \lambda}{\left(1+G_{F K}\right)^{i-1}\left(F K_{0}+(1-\gamma) k n[(1+\pi)(1+n) /(\pi n+\pi+n)]\left[(1+\pi)^{i-1}(1+n)^{i-1}-1\right] Y_{0} \Delta \lambda\right.}
$$

\section{ESTIMATION AND SIMULATION}

The parameters of the model, estimated as averages or compound growth rates using data for the past five to eight years, are given in Table 1. The data are taken from various issues of Annual Report and Economic Survey.

Table 1

The Parameter Estimates

\begin{tabular}{ll}
\hline \multicolumn{1}{c}{ Parameter } & Estimate \\
\hline Share of public sector in investment: $\lambda_{i}$ & 0.51 \\
Capital-output ratio: $k_{i}$ & 3.80 \\
Growth rate of GDP: $n_{i}$ & 0.047 \\
Marginal rate of tax: $t_{i}$ & 0.17 \\
Marginal rate of government consumption expenditure: $g_{i}$ & 0.12 \\
Marginal rate of private savings: $s_{i}$ & 0.15 \\
Marginal rate of unrequited transfers: $q_{i}$ & 0.05 \\
Nominal rate of interest on foreign debt: $r_{f i}$ & 0.036 \\
Real rate of interest on domestic debt:: $r_{d i}$ & 0.01 \\
Real rate of return on the private foreign capital: $\rho_{i}$ & 0.05 \\
Growth rate of the private foreign capital: $G_{F K i}$ & 0.18 \\
Growth rate of foreign reserves: $G_{F R i}$ & 0.15 \\
Growth rate of high powered money: $G_{M i i}$ & 0.13 \\
Rate of exchange rate depreciation: $e_{i}$ & 0.08 \\
Inflation rate: $\pi_{I}$ & 0.10 \\
\hline
\end{tabular}


Table 2 shows the results of simulation under the assumption that all the parameters retain their historic values. These results show that foreign and domestic borrowing and debt would grow exponentially at an annual compound rate between 15 percent and 20 percent over the next 25 years. These projections are in nominal terms and, hence, they include the effect of an assumed 10 percent inflation rate. To factor out the inflationary effects, the resource deficits are expressed as ratios to the nominal GDP. The last four columns of Table 2 show that these ratios are also expected to grow, though at a much lower rate. Foreign borrowing would increase from 2.4 percent of GDP in 1995-96 to 4.1 percent in 2019-20. Domestic borrowing would increase from 2.7 percent to 6.7 percent over the same period. These modest growth rates leave the already large volumes of foreign and domestic debt relatively stable. Foreign debt is expected to grow by a little less than 1 percent per annum while domestic debt would remain almost constant.

Domestic debt is expected to grow slower than the foreign debt despite the expectation that domestic borrowing would grow faster than the foreign borrowing. This is so because while the foreign debt measured in rupees also grows on account of an expected 8 percent depreciation of rupee per annum, there is no such indexation in case of domestic debt.

We now study the effects of the two policies to attract foreign capital inflow discussed in Section 2. The effects of increasing the rate of return on foreign capital $\rho$ depend on $\beta$, the degree of responsiveness in the growth rate of foreign capital $G_{F K}$ to changes in $\rho$. Various iterations over $\beta$ to determine the effects of an increase in $\rho$ by 1 percent from 5 percent to 6 percent resulted in a critical value: $\beta=0.8$ at which the increase in $\rho$ leaves negligible effects on resource deficits, in particular the net foreign borrowing and foreign debt. Thus an increase in the rate of return on foreign capital from 5 percent to 6 percent would have little effect on resource deficits if it results in an increase in the growth rate of foreign capital by 0.8 percent from 18 percent to 18.8 percent.

Now consider the effects of increasing $\rho$ by 1 percent, assuming alternatively that the resulting increase in the growth rate of foreign capital is high and low. The simulated effects of this policy with $\beta=1.6$ (high response) and $\beta=0.4$ (low response) are reported in Table 3 and Table 4 respectively.

With $\beta=1.6$ the unfavourable effect on foreign resource deficit of the increased factor payments abroad is more than offset by the favourable effect of the increased capital inflow. As a result net foreign borrowing and foreign debt decrease substantially. The reduced foreign borrowing in turn implies that government has to increase domestic borrowing for the following reason. Since the government's budget position does not improve as we explain below, any decrease in foreign borrowing must be offset by an increase in domestic borrowing. Alternatively, given the GDP growth rate and the share of private sector in investment expenditure, the increased foreign investment means an equal decrease in investment by the domestic private sector and thus an improvement in the private sector's current balance. The resulting surplus in domestic capital market must be borrowed by government to restore equilibrium. 
Table 2

Foreign and Domestic Borrowing and Debt

\begin{tabular}{lrrrrrrrr}
\hline Year & $F B i$ & $D B i$ & $F D i$ & $D D i$ & $F B / Y(\%)$ & $D B / Y(\%)$ & $F D / Y(\%)$ & $D D / Y(\%)$ \\
\hline $1995-96$ & 51 & 58 & 788 & 842 & 2.39 & 2.72 & 36.68 & 39.20 \\
$1999-00$ & 87 & 105 & 1393 & 1180 & 2.30 & 2.77 & 36.84 & 31.20 \\
$2003-04$ & 154 & 210 & 2452 & 1834 & 2.31 & 3.15 & 36.87 & 27.58 \\
$2007-08$ & 287 & 444 & 4355 & 3201 & 2.45 & 3.79 & 37.22 & 27.35 \\
$2011-12$ & 565 & 951 & 7894 & 6124 & 2.75 & 4.62 & 38.34 & 29.75 \\
$2015-16$ & 1182 & 2023 & 14777 & 12364 & 3.26 & 5.59 & 40.80 & 34.14 \\
$2019-20$ & 2595 & 4238 & 28828 & 25502 & 4.07 & 6.65 & 45.24 & 40.02 \\
\hline CGR & 17.77 & 19.55 & 16.18 & 15.27 & 2.25 & 3.80 & 0.88 \\
\hline
\end{tabular}


Table 3

Foreign and Domestic Borrowing and Debt $(\Delta \rho=0.1, \beta=1.6)$

\begin{tabular}{ccccccccc}
\hline Year & $F B i$ & $D B i$ & $F D i$ & $D D i$ & $F B / Y(\%)$ & $D B / Y(\%)$ & $F D / Y(\%)$ & $D D / Y(\%)$ \\
\hline $1995-96$ & 49 & 60 & 786 & 844 & 2.30 & 2.80 & 36.60 & 39.29 \\
$1999-00$ & 82 & 111 & 1374 & 1198 & 2.17 & 2.93 & 36.34 & 31.70 \\
$2003-04$ & 140 & 227 & 2383 & 1903 & 2.11 & 3.42 & 35.84 & 28.62 \\
$2007-08$ & 253 & 490 & 4152 & 3404 & 2.16 & 4.19 & 35.49 & 29.09 \\
$2011-12$ & 486 & 1065 & 7357 & 6664 & 2.36 & 5.17 & 35.74 & 32.37 \\
$2015-16$ & 997 & 2295 & 13434 & 13715 & 2.75 & 6.34 & 37.09 & 37.87 \\
$2019-20$ & 2175 & 4871 & 25600 & 28754 & 3.41 & 7.64 & 40.17 & 45.12 \\
\hline CGR & 17.08 & 20.09 & 15.62 & 15.84 & 1.66 & 4.27 & 0.39 & 0.58 \\
\hline
\end{tabular}


Table 4

Foreign and Domestic Borrowing and Debt $(\Delta \rho=0.1, \beta=0.4)$

\begin{tabular}{|c|c|c|c|c|c|c|c|c|}
\hline Year & $F B i$ & $D B i$ & $F D i$ & $D D i$ & $F B / Y(\%)$ & $D B / Y(\%)$ & $F D / Y(\%)$ & $D D / Y(\%)$ \\
\hline $1995-96$ & 54 & 56 & 791 & 840 & 2.50 & 2.60 & 36.80 & 39.09 \\
\hline 1999-00 & 92 & 98 & 1415 & 1158 & 2.45 & 2.59 & 37.42 & 30.62 \\
\hline 2003-04 & 165 & 194 & 2520 & 1766 & 2.48 & 2.92 & 37.89 & 26.55 \\
\hline 2007-08 & 308 & 411 & 4524 & 3031 & 2.64 & 3.51 & 38.66 & 25.90 \\
\hline 2011-12 & 609 & 882 & 8275 & 5741 & 2.96 & 4.29 & 40.20 & 27.89 \\
\hline 2015-16 & 1266 & 1884 & 15590 & 11544 & 3.49 & 5.20 & 43.04 & 31.87 \\
\hline $2019-20$ & 2756 & 3962 & 30502 & 23811 & 4.32 & 6.22 & 47.87 & 37.37 \\
\hline$C G R$ & 17.82 & 19.44 & 16.44 & 14.95 & 2.30 & 3.70 & 1.10 & -0.19 \\
\hline
\end{tabular}


With the foreign debt being gradually replaced by the domestic debt, government's budget deficit also increases since the interest rate on domestic debt is higher than the interest rate on foreign debt (including the effect of depreciating rupee). This puts further pressure to increase domestic borrowing. The results show that the increase in net domestic borrowing is slightly more than the decrease in net foreign borrowing and, therefore, the overall borrowing need of the government increases. The increase in the overall size of public (foreign plus domestic) debt is, however, negligible.

When the growth rate of foreign capital increases by one-half of the increase in the rate of return on foreign capital, that is $\beta=0.4$, the results are just the opposite (see Table 4). Thus the policy of offering a better returns on foreign investment can only replace foreign debt by the domestic debt. And even this happens when the inflow of foreign capital is sensitive enough to changes in the rate of return on foreign capital.

Coming to the second policy of attracting foreign capital, we consider the sale of public-sector enterprises that results in a permanent reduction in the government's share in investment expenditure $\lambda$ by 5 percent from 51 percent to 46 percent under four alternative assumptions on the crowding out of exogenous capital inflows: no crowding out $(\gamma=0)$, full crowding out $(\gamma=1), 50$ percent crowding out $(\gamma=0.5)$ and 50 percent crowding-in $(\gamma=-05)$. The results are reported in Table 5 to Table 8 .

In the absence of crowding out, the immediate effect of the policy is a substantial increase in the growth rate of foreign capital and a corresponding decrease in net foreign borrowing and foreign debt (Table 5). These benefits, however, quickly fade out since the nominal rate of return on foreign capital is much higher than the nominal rate of interest on foreign debt. As it turns out, in the long run the net foreign borrowing in fact increases and, as a result, the initial reduction on foreign debt is mostly offset within 25 years. The major benefit of the sale of public-sector enterprises is realised in terms of a significant reduction in net domestic borrowing and domestic debt that occurs due to a sizeable reduction in the primary fiscal deficit and its subsequent effects on the interest payments on domestic debt.

In case complete crowding out occurs (Table 6), net foreign borrowing and foreign debt are not affected where as net domestic borrowing and domestic debt decline significantly as before. With complete crowding out the net capital inflow in the country remains unaffected and to maintain the given growth rate of GDP, the decrease in investment in public sector is fully replaced by the domestic private investment. Thus the sale of public assets to foreign investors is practically equivalent to the sale to domestic investors.

The simulation results with partial crowding out and crowding in (or negative crowding out), presented in Table 7 and Table 8 respectively, do not show any fundamental difference from the previous two cases. It appears, therefore, that the usual argument in favour of selling public assets to foreign investors is not empirically 
Table 5

Foreign and Domestic Borrowing and Debt $(\Delta \lambda=-0.05, \gamma=0)$

\begin{tabular}{lrrrrrrrr}
\hline Year & $F B i$ & $D B i$ & $F D i$ & $D D i$ & $F B / Y(\%)$ & $D B / Y(\%)$ & $F D / Y(\%)$ & $D D / Y(\%)$ \\
\hline $1995-96$ & 32 & 58 & 769 & 842 & 1.49 & 2.72 & 35.79 & 39.20 \\
$1999-00$ & 70 & 81 & 1290 & 1123 & 1.85 & 2.14 & 34.12 & 29.70 \\
$2003-04$ & 138 & 136 & 2237 & 1571 & 2.07 & 2.05 & 33.64 & 23.62 \\
$2007-08$ & 274 & 265 & 3998 & 2406 & 2.34 & 2.27 & 34.16 & 20.56 \\
$2011-12$ & 563 & 559 & 7374 & 4128 & 2.73 & 2.71 & 35.82 & 20.05 \\
$2015-16$ & 1203 & 1207 & 14115 & 7828 & 3.32 & 3.33 & 38.97 & 21.61 \\
$2019-20$ & 2670 & 2600 & 28156 & 15816 & 4.19 & 4.08 & 44.18 & 24.82 \\
\hline CGR & 20.23 & 17.14 & 16.19 & 13.00 & 4.40 & 1.71 & 0.88 & -1.89 \\
\hline
\end{tabular}


Table 6

Foreign and Domestic Borrowing and Debt $(\Delta \lambda=-0.05, \gamma=1)$

\begin{tabular}{|c|c|c|c|c|c|c|c|c|}
\hline Year & $F B i$ & $D B i$ & $F D i$ & $D D i$ & $F B / Y(\%)$ & $D B / Y(\%)$ & $F D / Y(\%)$ & $D D / Y(\%)$ \\
\hline 1995-96 & 51 & 39 & 788 & 823 & 2.39 & 1.82 & 36.68 & 38.31 \\
\hline 1999-00 & 87 & 57 & 1393 & 1020 & 2.30 & 1.52 & 36.84 & 26.98 \\
\hline 2003-04 & 154 & 105 & 2452 & 1355 & 2.31 & 1.58 & 36.87 & 20.37 \\
\hline 2007-08 & 287 & 227 & 4355 & 2046 & 2.45 & 1.94 & 37.22 & 17.48 \\
\hline 2011-12 & 565 & 517 & 7894 & 3601 & 2.75 & 2.51 & 38.34 & 17.49 \\
\hline 2015-16 & 1182 & 1176 & 14777 & 7152 & 3.26 & 3.25 & 40.80 & 19.75 \\
\hline 2019-20 & 2595 & 2617 & 28828 & 15117 & 4.07 & 4.11 & 45.24 & 23.72 \\
\hline CGR & 17.77 & 19.13 & 16.18 & 12.89 & 2.25 & 3.44 & 0.88 & -1.98 \\
\hline
\end{tabular}


Table 7

Foreign and Domestic Borrowing and Debt $(\Delta \lambda=-0.5, \gamma=0.5)$

\begin{tabular}{lrrrrrrrr}
\hline Year & $F B i$ & \multicolumn{1}{c}{$D B i$} & \multicolumn{1}{c}{$F D i$} & $D D i$ & $F B / Y(\%)$ & $D B / Y(\%)$ & $F D / Y(\%)$ & $D D / Y(\%)$ \\
\hline $1995-96$ & 42 & 49 & 779 & 833 & 1.94 & 2.27 & 36.24 & 38.76 \\
$1999-00$ & 79 & 69 & 1341 & 1071 & 2.08 & 1.83 & 35.48 & 28.34 \\
$2003-04$ & 146 & 121 & 2345 & 1463 & 2.19 & 1.82 & 35.25 & 22.00 \\
$2007-08$ & 280 & 246 & 4176 & 2226 & 2.40 & 2.10 & 35.69 & 19.03 \\
$2011-12$ & 565 & 537 & 7635 & 3864 & 2.74 & 2.61 & 37.09 & 18.77 \\
$2015-16$ & 1194 & 1190 & 14452 & 7484 & 3.30 & 3.28 & 39.90 & 20.66 \\
$2019-20$ & 2637 & 2604 & 28512 & 15446 & 4.14 & 4.09 & 44.74 & 24.24 \\
\hline CGR & 18.87 & 18.03 & 16.19 & 12.94 & 3.21 & 2.48 & 0.88 & -1.94 \\
\hline
\end{tabular}


Table 8

Foreign and Domestic Borrowing and Debt $(\Delta \lambda=-0.5, \gamma=-0.5)$

\begin{tabular}{lrrrrrrrr}
\hline Year & $F B i$ & $D B i$ & $F D i$ & \multicolumn{1}{c}{$D D i$} & $F B / Y(\%)$ & $D B / Y(\%)$ & $F D / Y(\%)$ & $D D / Y(\%)$ \\
\hline $1995-96$ & 22 & 68 & 759 & 852 & 1.05 & 3.16 & 35.34 & 39.65 \\
$1999-00$ & 62 & 92 & 1239 & 1174 & 1.63 & 2.44 & 32.77 & 31.06 \\
$2003-04$ & 130 & 152 & 2131 & 1678 & 1.95 & 2.28 & 32.04 & 25.23 \\
$2007-08$ & 267 & 285 & 3820 & 2585 & 2.28 & 2.44 & 32.65 & 22.09 \\
$2011-12$ & 560 & 581 & 7113 & 4393 & 2.72 & 2.82 & 34.55 & 21.34 \\
$2015-16$ & 1210 & 1228 & 13771 & 8180 & 3.34 & 3.39 & 38.02 & 22.58 \\
$2019-20$ & 2698 & 2605 & 27769 & 16216 & 4.23 & 4.09 & 43.58 & 25.45 \\
\hline CGR & 22.08 & 16.41 & 16.18 & 13.06 & 6.00 & 1.08 & 0.88 & -1.83 \\
\hline
\end{tabular}


supported in our model. The only benefit of this policy is a reduction in the primary fiscal deficit and the resulting decrease in domestic borrowing and domestic debt. This benefit can, however, be realised by selling public assets to domestic investors as well.

\section{CONCLUSION}

The effects of two different policies to attract foreign investment on the foreign and domestic borrowings and debt are discussed within the framework of a three-gap simulation model applied to the economy of Pakistan. The policy of increasing the rate of return on foreign capital can reduce foreign debt only when foreign capital is sufficiently responsive to its rate of return. The improvement in foreign debt is, however, accompanied by a deteriorating position of domestic debt. The policy of selling public assets abroad to attract foreign capital is disappointingly fruitless. The benefit of this policy occurs mainly in terms of reduced primary fiscal deficit and the resulting decrease in domestic debt. This result can better be achieved by selling public assets domestically. Thus we conclude that the usual argument that the burden of foreign debt can be reduce by selling public-sector enterprises to foreign investors does not hold much ground.

\section{REFERENCES}

Ahmad, E. (1997) Debt Problem in Pakistan: What Policy Options Do We have? Seminar Series. Islamabad: Department of Economics, Quaid-i-Azam University and Friedrich Ebert Stiftung.

Ahmad, E., and S. Paul (1994) Foreign Capital, Institutional Arrangements and Economic Growth. School of Economics, The University of New South Wales, Australia. (Discussion Paper 94/16.)

Crouch, R. L. (1973) Economic Development, Foreign Aid, and Neoclassical Growth. Journal of Development Studies 9: 353-364.

Cohen, D. (1988) The Management of the Developing Countries Debt: Guidelines and Applications to Brazil. The World Bank Economic Review 2:1 77-103.

Easterly, W., and K. Schmidt-Hebbel (1993) Fiscal Deficits and Macroeconomic Performance in Developing Countries. The World Bank Research Observer 8:2 211-237.

Naqvi, S. N. H. (1970) The Foreign Capital Requirements and External Indebtedness of a Developing Country: A Case Study of Pakistan. In E. A. G. Robinson (ed) Economic Development in South Asia. London: M. Stockton 504-24.

Tanzi, V., M. I. Blejer and M. O. Teijeiro (1988) The Effects of Inflation on the Measurement of Fiscal Deficits. In M. I. Blejer and C. Ke-Young (eds) Measurement of Fiscal Impact: Methodological Issues. Washington, D. C.: International Monetary Fund. (Occasional Paper 59.) 4-16. 


\section{Comments}

First of all, I congratulate Dr Eatzaz Ahmad for this good paper that is well written and focused on an important issue of national concern; that is, the evaluation of the impact of various policies of resource mobilisation on debt reduction. The author has rightly stated that sustainable solution to the problem of resource constraints faced by Pakistan today is to raise the overall savings rate by increasing the national income through productivity growth; but the policy-makers have resorted to policies of shortterm relief like debt roll-over to deffer the bite of the resource constraints. He explores the effects of two different policies to attract foreign investment on foreign borrowing and debt. The policies that are considered are:

(i) increasing the return on foreign capital; and

(ii) selling public sector enterprises exclusively to foreign investors.

This impact is analysed in the context of a three gap general equilibrium growth model. The innovation in analysis being that the increase in foreign investment is used in reducing foreign debt rather than increasing the growth rate of GDP through investment. Given the general equilibrium specification of the model and the level of aggregation (or low level of disaggregation) involved in it the conclusions are correct for the two hypothetical policies that are analysed here. It should be known that the use of general equilibrium analysis is a tricky business for policy-making because we are dealing with identities where a reduction in the value of one variable automatically implies an increase in the value of the other; the behavioural factors loose their importance unless explicitly incorporated in the model.

In the following I will comment on the policy relevance of this analysis followed by some technical issues: In the present model, for example, a policy of disinvestment of public enterprise by privatisation leads to reduction in $I_{g i}$ in Equation (6), that leads to reduction in budget deficit. The proceeds from this privatisation when used to retire foreign debt $(F D)$ results in reduced foreign borrowing $(F B)$ and domestic borrowing $(D B)$ etc. But in case of Pakistan's implementation of privatisation programme, the privatisation proceeds are not entirely used for retiring foreign debt. Rather, these proceeds were used to finance large portions of current expenditures of the government as well as to finance social sector programmes like SAP. For example, by last year (1995) out of 40 billion rupees obtained from privatisation, only Rs 8 billion went to retire foreign debt that is only about 20 percent of the privatisation proceeds. In terms of the equations of this model it means that in Equation (6) as public investment $\left(I_{g i}\right)$ is going down due 
to privatisation of state-owned-enterprise public savings are also going down $\left(S_{g i}\right)$ due to rechannelling of it in other public expenditures. The consequence is that the budget deficit $\left(B D_{i}\right)$ does not decline hence no significant reduction in domestic or foreign borrowing. The level of aggregation used in the model does not allow for capturing of this possibility. Because of this missing aspect the model looses some policy relevance. It would be nice if the author also evaluate the consequences of the sale-to-consume and sale-to-invest policies on growth rates of domestic and foreign borrowing through their effect on output.

There is another way in which the reader is puzzled by the policy relevance of this analysis - the two policies analysed are hypothetical. Neither Pakistan has increased the real rate of return to foreigners $\rho$, nor it is selling public assets exclusively to foreigners.

How to increase real returns on foreign investment so as to attract foreign capital is itself a complex issue given the fact that political uncertainty is a big deterent to foreign capital inflow and that it is not a policy instrument that can be changed easily by discretionary control .

In the end Dr Eatzaz concludes that the "results can better be achieved by selling public assets domestically". But selling assets exclusively to domestic investors has its own problems.

1. Liquidity shortage in domestic economy, i.e., the domestic investors cannot afford to buy.

2. Domestic investors may not have incentives to purchase the assets offered for sale.

3. Domestic producers may not be very efficient as compared to foreign managers.

Transferring management from one group of inefficient managers (government) to the other inefficient group (domestic private sector) is not the objective of privatisation. Due to externalities associated with technology spillovers, experience etc. foreign managers may be able to achieve results not possible by domestic managers.

As far as I understand the present privatisation policy does not offer public assets for sale exclusively to foreigners. For example one can see privatisation of giants projects like PTC.

In the end let me come to a technical comment, i.e., the simulation technique used in this analysis is not specified. As long as the dynamic linkages between various variables and their growth rates are linear a simple simulation method will give correct results. But in non-linear systems there can be more than one critical values of $\beta$. In that case we have to check $\beta$ over the entire range of possible $\beta$ or we 
have to utilise some random search method with random perturbations. I also found some typographical mistakes that I will hand over to the author for correction in the final version.

To end this discussion I would say that the contribution of this paper is indeed a new thrust to the application of three gap model to Pakistan and its focus on the evaluation of debt reduction policies.

International Institute of Islamic Economics (IIIE),

\section{Syed Salman Ali}

International Islamic University,

Islamabad. 